\title{
Features of adaptation of photosynthesis of winter wheat plant leaves to growing conditions
}

\author{
A.V. Amelin ${ }^{1, *}$, E.I. Chekalin ${ }^{1}$, V.V. Zaikin ${ }^{1}$, and R.A. Ikusov ${ }^{2}$ \\ ${ }^{1}$ FSBEI HE Oryol State Agrarian University, CUC Plant Genetic Resources and their use, 302019, \\ Orel, Russia \\ ${ }^{2}$ FSBEI HE Oryol State Agrarian University, Department of Crop Production, Breeding and Seed \\ Production, 302019, Orel, Russia
}

\begin{abstract}
Depending on the growing conditions, the intensity of photosynthesis of winter wheat plant leaves varies from 7.58 to $15.76 \mu \mathrm{mol}$ $\mathrm{CO}_{2} / \mathrm{m} 2^{\mathrm{s}}$, significantly decreasing (on average by $41 \%$ ) in dry and hot weather. During the day, its value varies from 7.07 to $12.48 \mu \mathrm{mol}$ $\mathrm{CO}_{2} / \mathrm{m}^{2} \mathrm{~s}$, reaching a maximum $\left(12.48 \mu \mathrm{mol} \mathrm{CO} / \mathrm{CO}^{2} \mathrm{~s}\right)$ in the morning (from 9:00 to 11:00 am), when the air temperature is not so high (from 18 to $\left.23^{\circ} \mathrm{C}\right)$, and the light becomes saturating $\left(1000-1300 \mu \mathrm{mol} / \mathrm{m}^{2} \mathrm{~s}\right)$. In the time following, the intensity of leaf photosynthesis decreases, reaching the minimum values at 7:00 pm. At the same time, the flag leaves of plants are characterized by the highest photosynthetic activity - from 12.56 to 16.16 $\mu \mathrm{mol} \mathrm{CO} / \mathrm{m}^{2} \mathrm{~s}$, exceeding the pre-flag leaves by 1.6 times, and the lower ones by 3.1 times. The stomatal apparatus plays an important role in the adaptation of leaf photosynthesis to environmental factors. The correlation coefficient of photosynthesis intensity with stomatal conductivity in different leaf locations varied from 0.97 to 0.98 .
\end{abstract}

\section{Introduction}

The limited ability of plants to withstand extreme environmental factors (high temperatures, lack of moisture, etc.) determines the unusually high dependence of crop production on soil-climatic and weather conditions [1]. Their influence on the duration and nature of the growing season is so significant that it leads to a sharp decrease in yield and even complete planting failure [2]. At the same time, photosynthesis, which is the main factor of the plant production process, is the most vulnerable to the direct impact of environmental conditions $[3,4]$.

This determines the importance of studying the specific and genotypic features of photosynthesis processes and its adaptive capabilities in agricultural plants in order to identify effective ways to obtain a high, stable and high-quality grain yield. This issue is also very important for winter wheat, the main food crop in Russia and the world, which yield variability has only increased in recent decades [5].

\footnotetext{
${ }^{*}$ Corresponding author: amelin_100@mail.ru
} 


\section{Materials and methods}

The research was carried out on the material and technical base of the Common Use Center "Plant Genetic Resources and their use" of the FSBEI HE Orel SAU under a joint program with the FSBSI FSC for Legumes and Cereals. The objects of research were plants of 35 modern varieties and promising lines of winter wheat from the leading breeding institutions of Russia. The experimental material was grown in the Shatilovskaya Agricultural Experimental Station of the FSBSI FRS for Legumes and Cereals on plots with an area of $25 \mathrm{~m}^{2}$ in 4-fold repetition, the placement was randomized.

Photosynthesis activity indicators were recorded in real time on intact plants using a modern portable gas analyzer GFS-3000 FL of the German company WALZ. For the measurement, the leaves without visible damage were taken from 5-7 typical genotype plants growing in the middle of the plot. The readings were taken from the leaves of different tiers (flag, pre-flag and lower) during the day (from 6:00 to 19:00 am Moscow time) and during the main growth phases (I - Tillering, II - Stem extension, III - Earing, IV - Flowering, V - Filling, VI - Milky-wax ripeness). Statistical processing and calculation of correlations based on the results of experimental studies were carried out using modern computer programs.

\section{Results and discussion}

It was previously shown that in the ontogenesis of winter wheat plants, the intensity of leaf photosynthesis begins to increase actively from the tillering phase, reaching its maximum value during the "flowering - grain formation and filling", which is mainly due to a sharp increase in the demand for photo assimilates at this time. But then, as the leaves age, its value begins to decrease incrementally until the phase of grain milky-wax ripeness. In the flowering phase, the value of this indicator in the experimental cultivars was on average $18 \%$ higher, compared with the phases "tillering", "stem extension" and "milk-wax ripeness". In the reproductive period of development, genotypic differences are most significantly manifested. The range of varietal variation of the average value of photosynthesis intensity in the experimental crop sample was in the range from 1.97 to $18.65 \mu \mathrm{mol} / \mathrm{m} 2 \mathrm{~s}$., including in 2015 it was $2.36-18.41 \mu \mathrm{mol} \mathrm{CO} 2 / \mathrm{m} 2 \mathrm{~s}$, in $2016-3.99-10.30$ $\mu \mathrm{mol} \mathrm{CO} 2 / \mathrm{m} 2 \mathrm{~s}$, and in $2017-10.32-25.63 \mu \mathrm{mol} \mathrm{CO} 2 / \mathrm{m} 2 \mathrm{~s}[6]$.

Along with this, it is shown that the intensity of leaf photosynthesis significantly depends on the growing conditions of plants. In the years of research (2015-2019), its values in the phase of milk ripeness varied in the range from 7.58 to $15.76 \mu \mathrm{mol} \mathrm{CO} / \mathrm{m}^{2} \mathrm{~s}$. Most of all, the photosynthesis of leaves under the influence of high air temperature was suppressed, which was noted in 2015, 2016 and 2019. The stress effect of this factor on photosynthesis is especially strong in conditions of moisture deficiency. In 2016, for this reason, the intensity of $\mathrm{CO}_{2}$ assimilation by plant leaves in the phase of grain milk ripeness was reduced by an average of $48.6 \%$, while in 2015 - by $28.4 \%$, and in 2019 - by $20.8 \%$, compared to 2017 and 2018, which were more favorable in terms of humidification and air temperature (Fig. 1). 


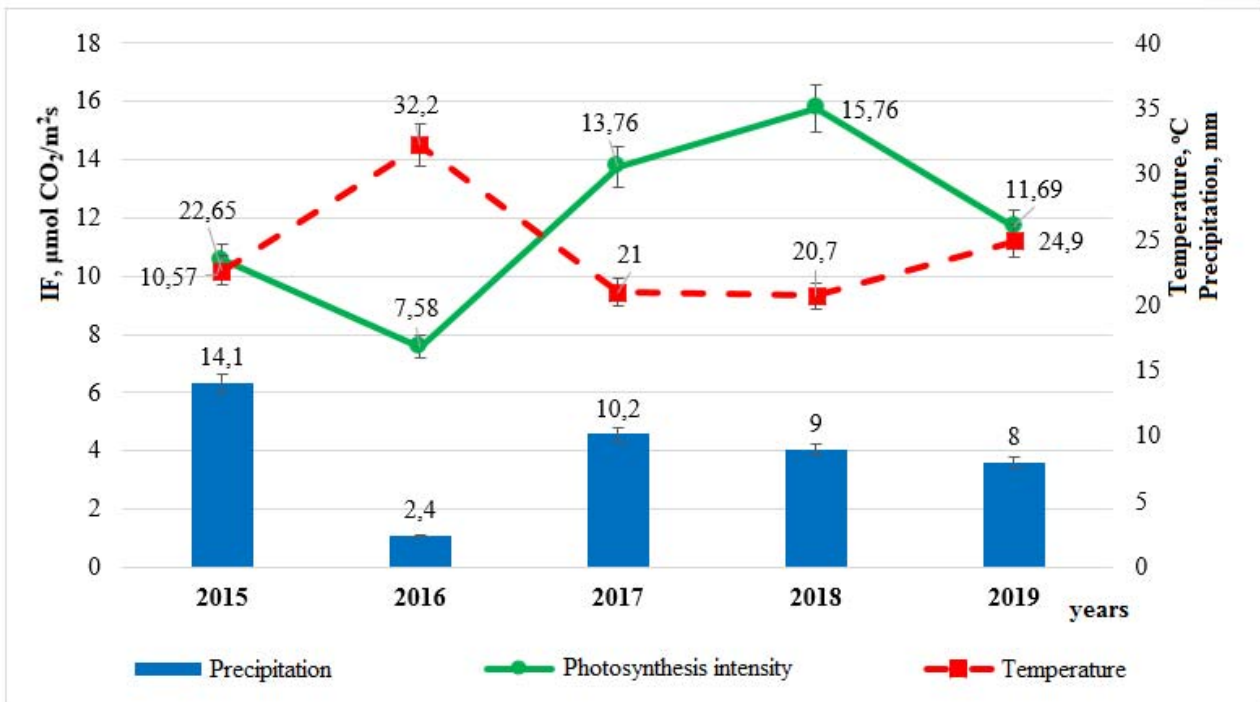

Fig. 1. Influence of weather factors (air temperature on day of measurement and precipitation (for a decade before measurement) on the photosynthesis intensity (IF, $\mu \mathrm{mol} \mathrm{CO}_{2} / \mathrm{m}^{2} \mathrm{~s}$ ) of winter wheat plants, in milk ripeness phase, in the years of research.

It is known that in the adaptation of photosynthesis to environmental factors, an important role is played by the stomatal apparatus of plants, which controls the entry of both carbon dioxide and water molecules into the intercellular space of leaves $[7,8,9]$. In this case, leaf transpiration provides not only active movement of minerals and water from the soil to the aboveground organs of the plant, but also protects them from overheating and dehydration in dry and hot weather, creating the conditions necessary for photosynthesis [9, $10]$.

Therefore, the efficiency of these physiological process interaction, which is largely determined by the stomatal conductivity of the leaves, significantly depends on the intensity of plant growth and the formation of their final yield [11].

In the years of research (2017-2019), the correlation coefficient between photosynthesis intensity and transpiration intensity on average during the growing season was significant and varied in the range from 0.45 to 0.55 . The strongest relationship $(\mathrm{r}=0.55)$ of these two processes was observed in 2017, and the weakest $(r=0.45 \ldots 0.47)-$ in 2018 and 2019. The relationship between the intensity of photosynthesis and transpiration was less significant with the stomatal conductivity of plant leaves, but it was also positive: correlation coefficient averaged by year 0.20 and 0.48 , respectively, during grain milky ripeness phase (Fig. 2). 


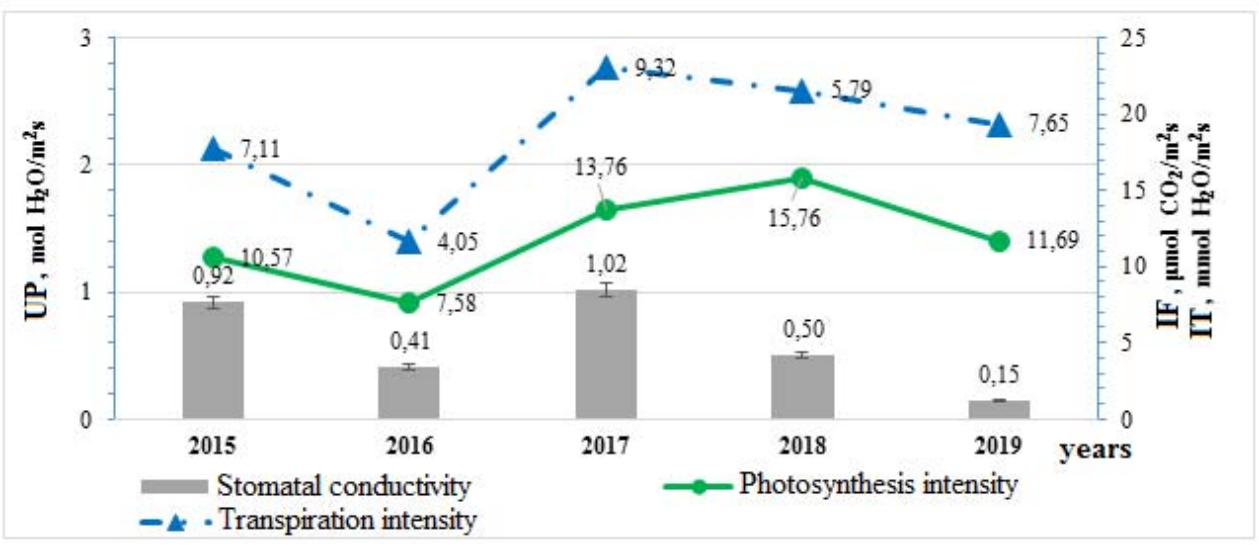

Fig. 2. Intensity of photosynthesis (IF, $\mu \mathrm{mol} \mathrm{CO}_{2} / \mathrm{m}^{2} \mathrm{~s}$ ), transpiration (IT, mmol $\mathrm{H}_{2} \mathrm{O} / \mathrm{m}^{2} \mathrm{~s}$ ), and stomatal conductivity (UP, $\mathrm{mol} \mathrm{H} \mathrm{H}_{2} \mathrm{O} / \mathrm{m}^{2} \mathrm{~s}$ ) of winter wheat plant leaves in the years of research.

Under the influence of exogenous factors, the photosynthetic activity of plant leaves also changes significantly during the day [12].

In our studies, the highest intensity of photosynthesis was observed in the morning (from 8:00 to 11:00 am), reaching a maximum $\left(12.48 \mu \mathrm{mol} \mathrm{CO}_{2} / \mathrm{m}^{2} \mathrm{~s}\right.$ ) at 9:00 am Moscow time, and then gradually decreased, following an increase in air temperature and insolation. Its minimum values were recorded at 7:00 pm (Fig. 3).

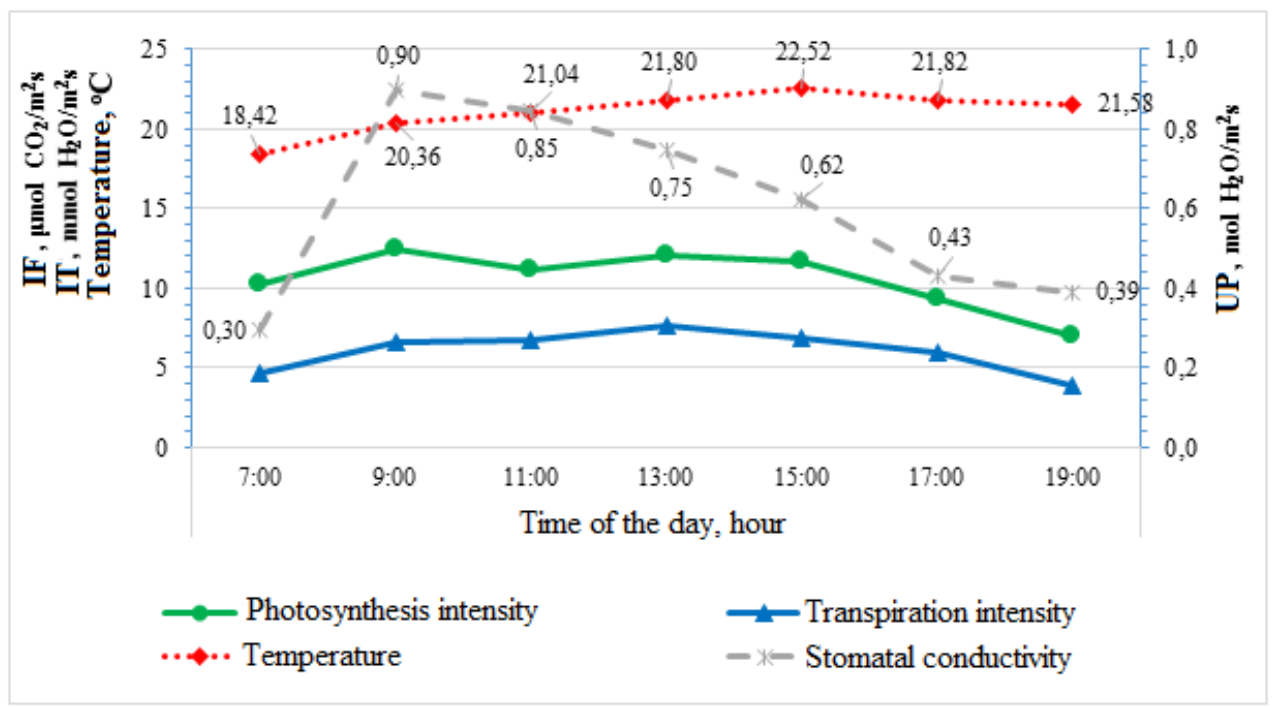

Fig. 3. Intensity of photosynthesis intensity (IF, $\mu \mathrm{mol} \mathrm{CO} 2 / \mathrm{m}^{2} \mathrm{~s}$ ), transpiration (IT, $\mathrm{mmol} \mathrm{H}_{2} \mathrm{O} / \mathrm{m}^{2} \mathrm{~s}$ ) and stomatal conductivity (UP, $\mathrm{mol} \mathrm{H}_{2} \mathrm{O} / \mathrm{m}^{2} \mathrm{~s}$ ) of winter wheat plant leaves, air temperature depending on the time of the day (Moscow local time).

In the morning $(9: 00 \mathrm{am})$, the light intensity was $1000-1100 \mu \mathrm{mol} / \mathrm{m}^{2} \mathrm{~s}$, and the air temperature was $18-21^{\circ} \mathrm{C}$, while at lunchtime, the values of these indicators varied in the range from 1700 to $1800 \mu \mathrm{mol} / \mathrm{m}^{2} \mathrm{~s}$ and from 21 to $23^{\circ} \mathrm{C}$, respectively. In the afternoon, the illumination decreased to $600-700 \mu \mathrm{mol} / \mathrm{m}^{2} \mathrm{~s}$, and the air temperature remained the same 21-22 ${ }^{\circ}$ C. (see Fig. 3). 
The pronounced decline in photosynthetic activity in the afternoon (after 3:00 pm) is primarily caused by the increased air temperature, which causes dehydration and overheating of leaf cells [13].

Depending on the tier arrangement on the plant, the highest photosynthetic and transpiration activity was observed in the flag leaves. In the years of research, the intensity of their photosynthesis averaged $14.36 \mu \mathrm{mol} \mathrm{CO} / \mathrm{m}^{2} \mathrm{~s}$, transpiration intensity $-5.40 \mathrm{mmol}$ $\mathrm{H}_{2} \mathrm{O} / \mathrm{m}^{2} \mathrm{~s}$. In pre-flag leaves, the intensity of gas exchange was $60 \%$, and transpiration intensity was $11 \%$ lower. But the lower leaves functioned the worst, which was closely related to their stomatal conductivity. In flag leaves, the conductivity of water molecules averaged $0.74 \mathrm{~mol} \mathrm{H} \mathrm{H}_{2} \mathrm{O} / \mathrm{m}^{2} \mathrm{~s}$, in pre-flag leaves - $0.46 \mathrm{~mol} \mathrm{H}_{2} \mathrm{O} / \mathrm{m}^{2} \mathrm{~s}$, and in lower leaves $0.36 \mathrm{~mol} \mathrm{H}{ }_{2} \mathrm{O} / \mathrm{m}^{2} \mathrm{~s}$ (Fig. 4).

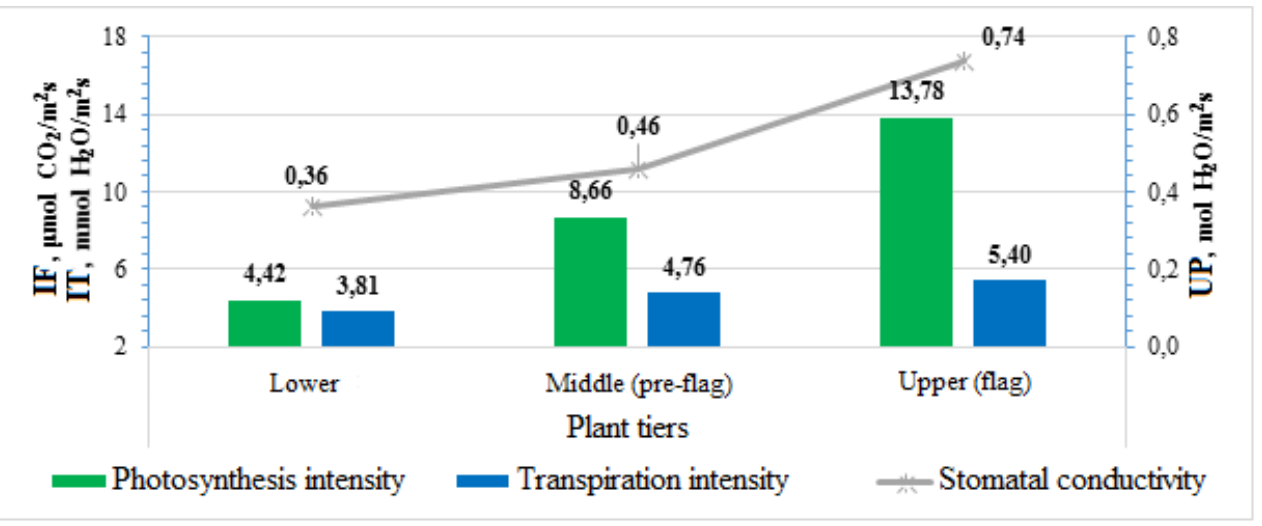

Fig. 4. Intensity of photosynthesis (IF, $\mu \mathrm{mol} \mathrm{CO}_{2} / \mathrm{m}^{2} \mathrm{~s}$ ) and transpiration (IT, $\mathrm{mmol} \mathrm{H}_{2} \mathrm{O} / \mathrm{m}^{2} \mathrm{~s}$ ) of winter wheat plants depending on tier arrangement of leaves.

In the years of the study (2017-2020), the value of correlation coefficient of stomatal conductivity with the intensity of photosynthesis in different leaf locations varied from 0.97 to 0.98 , and with the intensity of transpiration - from 0.83 to 0.99 . The correlation coefficient between the IF and IT of leaves, depending on their tier arrangement, was in $2017+0.92$, in $2018+0.93$, in 2020 0.98. (see Figure 4).

The tier differences in the photosynthetic activity of leaves are explained by different fruit loads [14,15,16], age characteristics [17,18], and different illumination [19].

In winter wheat plants, the highest fruit load is experienced by the flag leaves, which are physiologically younger and more illuminated in comparison with others, as a result of which they have the highest photosynthetic activity.

\section{Conclusion}

The photosynthesis intensity of winter wheat leaves largely depends on the weather and environmental conditions of the growing season (temperature, water and light modes), the growth phase, the location on the plant and the time of the day, which must be taken into account when assessing the genetic resources of the crop. The stomatal apparatus of plants, in this case, plays an important role in the adaptation of their photosynthetic system to environmental factors, controlling the movement of carbon dioxide and water molecules into the intercellular space of the leaves. 


\section{References}

1. A.A. Zhuchenko, Ways of innovative and adaptive development of the agro-industrial complex of Russia in the XXI century (Kirov: NIISH of the North-East, 143, 2011)

2. A.A. Wurbs, Archive for arable farming, crop production and soil science, 30 (2), 81 89 (1986)

3. A.A. Nichiporovich, Energy efficiency of photosynthesis and plant productivity, NC BI of the USSR Academy of Sciences, 37 (1979)

4. U. Schurr, A Walter., U. Rascher, Plant, Cell and Environment, 29, 340-352 (2006) doi: $10.1111 / \mathrm{j} .1365-3040.2005 .01490 . x$

5. A.A. Zhuchenko, Ensuring food security in Russia in the XXI century on the basis of an adaptive strategy for sustainable development of the agro-industrial complex: (theory and practice) (Kirov: NIISH of the North-East, 273, 2009)

6. A.V. Amelin, E.I. Chekalin, V.V. Zaikin, I.V. Kuleshova, V.I. Mazalov, A.V. Sagin, Successes of Moder Natural Science, 11, 18-23 (2018)

7. C.J. Atkinson, M. Policarpo, A.D. Webster, G. Kingswell, Tree Physiology, 20 (8), 557-563 (2000). Doi: https://doi.org/10.1093/treephys/20.8.557

8. F. Li, S. Cohen, A. Naor, K. Shaozong, A. Erez, Agricultural Water Management. 55, 1-14 (2002) Doi: https://doi.org/10.1016/S0378-3774(01)00184-6

9. R.A. Fischer, D. Rees, K.D. Sayre, Z.-M. Lu, A.G. Condon, A.L. Saavedra, Crop Science. 38, 1467-1475 (1998) Doi: 10.2135/cropsci1998.0011183X003800060011x.

10. W.J. Davies, S. Wilkinson, B. Loveys, New Phytologist, 153, 449-460 (2002)

11. F. Li, S. Cohen, A. Naor, K. Shaozong, A. Erez, Agricultural Water Management, 55, 1-14 (2002)

12. A.A. Krasnovsky, F.F. Litvin, Photosynthesis (M.: Mir, 1-2, 727, 1987)

13. C.C. Ma, Y.B. Gao, H.Y. Guo, J.L. Wang, Photosynthetica, 42 (1), 65-70 (2004)

14. V.A. Kumakov, Leaf apparatus as an object for evaluating grain crops in breeding under conditions of insufficient moisture // Plant Physiology in aid of breeding. - M., 213-225 (1974).

15. M.S. Lopes, N. Cortadellas, T. Kichey, Planta. 225 (1), 165-181 (2006) Doi: 10.1007/s00425-006-0338-5.

16. R. Sanchez-Bragado, G. Molero, M.P. Reynolds, J.L. Araus, Journal of Experimental Botany, 67 (9), 2787-2798 (2016)

17. V.R. Zalensky, News of the Kiev Polytechnic Institute, IV (1), 1-209 (1904)

18. A.T. Mokronosov, Ontogenetic aspect of photosynthesis (M.: Nauka, 169, 1981)

19. M. Monsi, T. Saeki, Annals of Botany, 95, 549-567 (2005) 